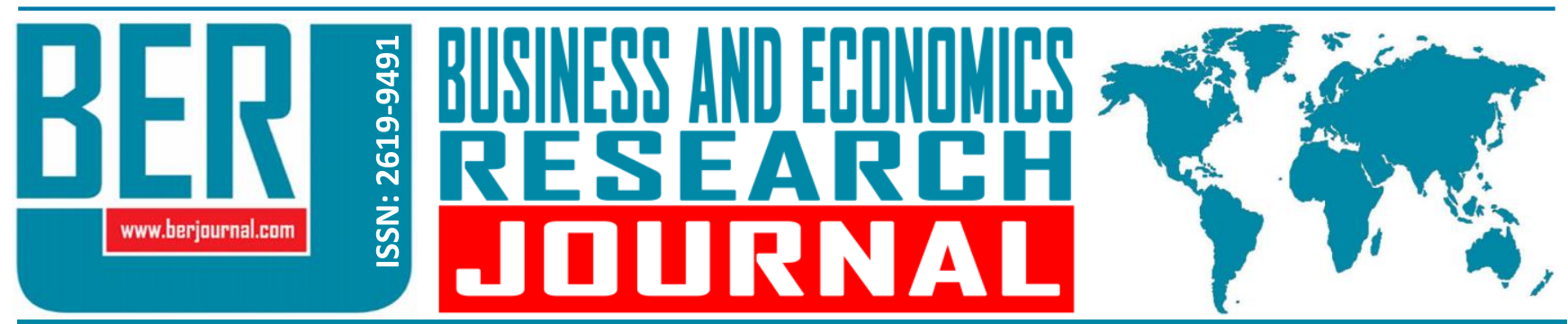

Business and Economics Research Journal Vol. 10, No. 1, 2019, pp. 149-165 doi: 10.20409/berj.2019.160

\section{Kalite Odaklı Liderliğin Kalite Performansı Üzerindeki Etkisinin Yapısal Eşitlik Modeli İle Analizi*}

\section{Bulent Yildiz}

Öz: Bu çalışmada kalite odaklı liderliğin eğitim, müşteri ve çalışan ilişkileri ile kalite performansı üzerindeki etkisi araştırılmıştır. Ayrıca çalışmada eğitimin müşteri ve çalışan ilişkileri üzerindeki etkisi incelenmiştir. Bu amaçla Gaziantep, Kahramanmaraş ve Adıyaman illerinde faaliyet göstermekte olan 170 imalat firmasından anket ile veri toplanmıştır. Veriler yapısal eşitlik modeli ile analiz edilmiştir. Yapılan analiz neticesinde kalite odaklı liderliğin eğitimi, çalışan ilişkilerini, müşteri ilişkilerini ve kalite performansını pozitif yönde anlamlı olarak etkilediği bulgusuna ulaşılmıştır. Eğitimin müşteri ilişkileri ve çalışan ilişkilerini pozitif yönde anlamlı olarak etkilediği tespit edilmiştir.

\section{Analysis of Quality Focus Leadership on Quality Performance by Structural Equation Modelling}

Abstract: In this study, the effect of quality-focused leadership on education, customer and employee relationships and quality performance was investigated. In addition, the effect of training on the customer and employee relationships has been examined. For this purpose, survey data were collected from 170 manufacturing companies operating in Gaziantep, Kahramanmaraş and Adıyaman. The data were analyzed by the structural equation model. As a result of the analysis made, it was found that the quality-focused leadership has a significant effect on training, employee relations, customer relations and quality performance positively. It was found that education significantly influenced customer relationships and employee relations positively.
Anahtar Sözcükler: Kalite Odaklı Liderlik, Eğitim, Müşteri ve Çalışan İlişkileri, Kalite Performansı

JEL: M10, M11, C12, C13, C83

Geliş : : 10 Eylül 2018

Düzeltme : 26 Ekim 2018

Kabul : : 07 Kasım 2018

Tür : : Araştırma

Keywords: Quality-Focused Leadership, Training, Customer and Employee Relationships, Quality Performance

JEL: M10, M11, C12, C13, C83

Received : 10 September 2018

Revised : 26 October 2018

Accepted : 07 November 2018

Type : Research 


\section{Giriş}

Globalleşmenin etkisi, teknolojinin hızla ilerlemesi, müşteri ihtiyaç ve beklentilerindeki değişimlerin artması, rekabet boyutlarındaki farklılaşmalar, yönetim biçimlerinin değişimine yol açarak Toplam Kalite Yönetiminin (TKY) doğmasına neden olmuştur. TKY, temel değerlerden, yöntem ve araçlardan meydana gelen, amacı daha az kaynakla organizasyon dışı ve organizasyon içi müşteri memnuniyetini artırmak olan sürekli değişen bir yönetim sistemidir (Klefsjö vd., 2007:121). TKY'nin etkisi son yıllarda daha fazla kendisini göstermiş ve organizasyonun bütün evrelerinde uygulanma zorunluluğu hissedilmiştir.

TKY'nin odağını oluşturan 'Kalite' kavramına ilişkin yazında değişik yazarlar tarafından yapılmış kalite tanımları bulunmaktadır. Shewhart kaliteyi "malın mükemmelliği", Juran "kullanıma ve amaca uygunluk", Crosby "sıfır hata", Feigenbaum "tüketici ihtiyaçlarını mümkün olan en ekonomik seviyede karşılamayı amaçlayan mühendislik, imalat ve pazarlama özelliklerinin bileşimi", Taguchi "ürünün dağıtımından sonra toplumda meydana getirdiği en az zarar" olarak tanımlamışlardır (Halis, 2008:3-4). Deming'in kalite yaklaşımı ise şu ifadesinden anlaşılmaktadır: "Yapabileceğinizin en iyisini yapmanız yetmez; ne yapacağınızı bilmeniz ve sonra en iyisini yapmanız gerekir" (Efil, 2016:89).

TKY, müşteri odaklı yönetim anlayışı olarak da bilinmektedir ve asıl amacı; müşterilerin istek ve beklentileri doğrultusunda ürün kalitesinin ve verimliliğinin artıııımasıdır. Bu nedenle, çalışanların performans değerlendirmesi ve ödüllendirilmesi, eğitimi, çalışan memnuniyetinin arttırıması, iyi bir ekip çalışması gerçekleştirilmesi, organizasyondaki hataların tamamen ortadan kaldırılması gibi hedefleri bulunmaktadır (Işı̆̆ıçok, 2005:21-22).

TKY, yönetim biçimi ve organizasyon kültürüne olan geniş kapsamlı etkileri ile organizasyonlar için büyük ve uzun vadeli bir meydan okuma olarak görülebilir. Müşteri memnuniyeti kapsamında tüm çalışanları ilgilendiren bir iç müşteriler zincirinin tanımlanmasıyla, müşteri odaklı olmaya yönelik bir girişim içerir. Bu nedenle, bürokratik ve uzmanlaşma odaklı bir anlayıştan uzaklaşmaya çalışarak bunun yerine sürekli gelişimi sağlamak için işbirliğine dayalı ekip çalışması ve çalışanların katılımını vurgular (Wilkinson vd., 1998:177).

Yazarlar, üst yönetimin uzun süreli kararlılığı olmadan TKY'nin bir işe yaramayacağına dikkat çekmektedir ve bu konuda oldukça hemfikirdir. Yöneticilerin ve çalışanların kalite araçlarının ve tekniklerinin kullanımı konusunda eğitim almaları gerektiği dünya genelinde kabul edilmiştir. Benzer olarak kalite sorunlarının çözümü, kurumun çeşitli seviyelerinde görevler arası iletişimi gerektirmektedir. Bu da genellikle ekipleri oluşturmak ve kullanmak anlamına gelir. Sonuç olarak TKY'nin, tüm bireylerin kaliteyle ilgilendiği, kaliteli ürünler üretmek istediği ve kalite üretmeyen uygulamaları özgürce sorgulayabildikleri bir kurum kültürü gerektirdiği konusunda yazarlar hem fikirdir (Reed vd., 2000:7).

Crosby'nin geliştirdiği 14 maddelik kalite iyileştirme sürecinin içerisinde bulunan 'TKY'nin bir organizasyonda etkin biçimde uygulanabilmesi için en önemli husus yönetimin kalite felsefesini benimseyip bu felsefeye inanması ve kendisini adamasıdır" maddesi TKY'nde yönetimin liderliğinin ne kadar önemli olduğuna vurgu yapmaktadır (Çetin, 2015:201). TKY anlayışı içerisinde eğitim faaliyetlerinin yürütülmesi, müşteri ve çalışan ilişkilerinin geliştirilmesi ve nihayetinde kalite performansının arttırılabilmesi için kalite odaklı liderlere ihtiyaç bulunmaktadır.

\section{Kuramsal Çerçeve}

Bu bölümde kalite odaklı liderlik, eğitim, müşteri ilişkileri, çalışan ilişkileri ve kalite performansı ile ilgili kuramsal açıklamalarda bulunulmuştur.

\subsection{Kalite Odaklı Liderlik}

Lider, "başkalarını belirli amaç doğrultusunda davranmaya sevk eden, onlara ilham veren ve onları etkileyen, o kişilerin kendisini isteyerek izlemesini sağlayan kişi” olarak tanımlanmaktadır (Koçel, 2014:668).

Yöneticilerin yalnızca bir alanda yeterli olması beklentisi geçmişte kalmıştır. Bugün yöneticiler yönetim ekibinin bir parçası olmalıdır ve organizasyondaki bütün departmanlarda görev yapan yöneticilerin sorumlulukları hakkında iyi bir temel bilgiye sahip olmalıdırlar. Örneğin, kalite müdürü; tasarım mühendisliği, 
imalat mühendisliği, satın alma, satış, üretim kontrolü, müşteri hizmetleri ve diğer tüm bölümlerin nasıl işlediğini anlamalıdır. Ve her yönetici diğerlerinin rollerini bilmelidir. Bu, her alanda o işi yapanlar kadar iyi eğitilmiş olmaları anlamına gelmez, önemli olan tüm organizasyonun nasıl işlediğini anlamalarıdır (Pekar, 1995:3-4).

Liderin rolleri aşağıdaki gibi açıklanabilir (Deming, 2000:125-128).

- Bir yönetici bir sistemin ne olduğunu anlar ve bunu kendi çalışanlarına iletir. Sistemin amaçlarını açıklar. Çalışanlarına ekip çalışmalarının bu hedefleri nasıl desteklediğini öğretir.

- Çalışanlarının kendilerini bir sistemin bileşenleri olarak görmelerine, amaçların gerçekleştirilmesine yönelik hem önceki hem sonraki tüm aşamalarda çabaların en iyi hale getirilmesine yönelik olarak işbirliği içinde çalışmalarına yardımcı olur.

- Çalışanlarının her biriyle yılda en az bir kere, onlar hakkında hüküm vermek için değil sadece onları dinlemek için samimi, telaşsız bir sohbet yapar. Amaç, çalışanları, amaçlarını, umut ve korkularını anlamak olacaktır. Yöneticilerin toplantıyı önceden planlamayarak doğal bir ortamda gerçekleştirmesi önemlidir.

- İşbirliğinin faydalarını ve insanlar ile gruplar arasındaki rekabetten kaynaklanan kayıpları anlar.

Yönetim liderliğinin TKY'ni başarılı bir şekilde uygulanmasında önemli katkısı vardır. Yöneticilerde idare-kalite liderliği bilgisi, önceliklendirme yeteneği, sistemler hakkında idari bilgi, kalite hakkında idari bilgi ve değişim yönetimi hakkında idari bilgi becerileri bulunmalıdır. Üst düzey yönetici bu becerileri ortaya koyduğu zaman TKY uygulamalarının daha başarılı olduğu görülmektedir. Antonaros (2010), üst düzey yöneticilere sadece sistem planlaması ve düşüncesi hakkında değil, aynı zamanda kalite sistemleri hakkında da derinlemesine eğitim verme ihtiyacının altını çizmiştir (Bon ve Mustafa, 2013:524-525).

Liderlik; vizyon, misyon, değerler, politika ve strateji, sistemler vb. ile başlayan, TKY'nin diğer ilke ve kavramlarıyla da devam eden kalite geliştirme sürecinin başlangıcıdır (Dahlgaard vd., 2008:214).

Liderlik, organizasyonu artan performansa kanalize eden hedeflerin belirlenmesinden sorumludur. Deming (1986) ve Juran'a (1989)'a göre liderler, organizasyonda kaliteli bir sürecin uygulanmasından sorumludur. Liderler, kalite meselelerinde, çalışanlardan daha fazla sorumludur. Ayrıca liderler, kişilere hedefleri gerçekleştirme yönünde rehberlik eder (Hassan vd., 2013:3).

Üst yönetim desteği, TKY'nin muhtemelen en önemli ilkesidir. TKY'ndeki üst düzey yönetim desteği, üst yönetimin ilham verici bir vizyon sunmayı, herkes tarafından anlaşılan stratejik yönler belirlemeyi ve çalışanları yönlendiren değerleri teşvik etmeyi gerektirir. TKY'nin başarılı olması için üst yönetim kendini çalışan idaresine adamalıdır (Kongpichayanond, 2013:28).

Juran'a göre bir kurumdaki bir CEO'nun kaliteyi sağlaması için atması gereken adımlar arasında kalite yönetimi konusunda tüm organizasyon çalışanlarına eğitim verilmesine ilişkin hüküm oluşturmak bulunmaktadır (Thiagarajan ve Zairi, 1997:273).

TKY anlayışı kapsamında yöneticiler sadece çalışanlara emirler veren ve işleri takip eden kişiler olmaktan uzaklaşıp, bütün personelin görüşlerine ve fikirlerine saygı duyan, ileri görüşlü bir vizyona sahip, personelin eğitimine önem veren, eğitimi gereksiz bir masraf olarak görmeyen, tüm odağını müşterileri memnun etmek üzerine kuran ve organizasyonun da bu amaç doğrultusunda yönlendiren, tedarikçileri organizasyonun bir paydaşı olarak gören ve onlarla uzun süreli ilişkiler geliştirmenin önemini bilen, departmanlar arasındaki koordinasyonun önemini bilen ve bütün çalışanlarına bu bilinci aşılayabilen ve nihayetinde TKY amaçları doğrultusunda organizasyondaki tüm bireyleri peşinden sürükleyebilen liderler olmalıdırlar.

\subsection{Eğitim}

Ishikawa'nın "Kalite eğitimle başlar ve eğitimle biter." sözü TKY'nde eğitimin ne kadar önemli olduğuna vurgu yapmaktadır (Ersoy ve Ersoy, 2015:75). 
Eğitim, kaliteli method ve araçlar üzerine kurulabilir. Üst yönetim, çalışanların bu yeni metot ve araçların kullanımı konusunda eğitim almalarını sağlayabilir. Kalite teknik ve araçlarının başarılı bir şekilde uygulanabilmesi için en temel koşullar, yönetimin tam desteği ve taahhüdü, doğru insanlara doğru zamanda gereken eğitimin verilmesidir (Tari vd., 2007:488). Eğitim intiyaçları faaliyette bulunulan sanayi koluna, organizasyon yapısına, personelin görev ve sorumluluklarına göre değişiklik göstermektedir. Bu nedenle uygulanacak eğitim programlarının müfredatı değişen ihtiyaçlara uygun olarak belirlenmelidir. Yapılan görevin niteliğine, çalışanların bilgi ve becerilerine göre ihtiyaç duyulan eğitimin kapsamı belirlenmelidir (Kıngır, 2013:67).

Eğitim, devam eden bir süreçtir ve çalışanlara yeni yönetim tarzlarını ve çalışma araçlarını göstermek için gereklidir. İstatistiksel kontrol çizelgelerinin nasıl kullanılacağı, iş süreçlerini iyileştirmek ve organizasyonun kalitesini yükseltmedeki rollerini anlamaları için gereken beceriler konusunda çalışanların eğitilmeleri gerekir. Eğitim tek seferlik bir çaba değildir. Çalışanlar, teorinin yetersizliğini ve gözden geçirilmesine olan ihtiyacı ancak eğitim ve öğretim yoluyla görebilirler. Eğitim yoluyla mevcut çalışma uygulamalarına eleştirel bir gözle bakabilir, bazı faaliyetlerini sorgulayabilir, alternatifleri değerlendirebilir ve belki de yeni yöntemler geliştirebilirler. Eğitim, onlara yenilikçi olmaları, işlerini daha iyi anlamaları ve performanslarını geliştirmeleri konusunda yardımcı olur (Madu, 1998:8).

Kalite eğitiminin temel özellikleri de aşağıdaki gibi özetlenebilir (Conti, 2012:238):

- Esnekliği geliştirme,

- Sürekli iyileştirmeye bağlı sürekli öğrenme,

- Müşteriye odaklanma,

- Süreçlere bağlı matris tabanlı yaklaşım doğrultusunda ekip çalışmasına önem verme,

- Süreç yönetimine önem verme,

- Bilginin ölçümüne ve optimum kullanımına göre olgusal bir düşünce tarzını kazanma,

- Bir sürecin etkinliğini (kalite) ve verimliliğini (maliyet ve zaman) iyileştirmek için tasarlanan metodolojiler ve tekniklerle ilgili eğitim alma.

TKY'nin öneminin çalışanlara anlatılabilmesi, kalite yönetim uygulamaları (KYU) hakkında çalışanların bilgilendirilebilmesi, müşteri odaklılık anlayışının organizasyondaki tüm bireylere benimsetilebilmesi, üretim süreçleri ile ilgili personelin etkinliğinin artırılabilmesi, sürekli iyileştirme kapsamında iş görenler arasındaki fikir alışverişinin sağlanabilmesi ve departmanlar arasındaki iletişimin ve işbirliğinin arttırılabilmesi için eğitim bir organizasyon için son derece önemlidir.

\subsection{Müşteri iliş̧kileri}

Günümüzde artık müşteriler kendileri ile birebir iletişim kurulmasını, ihtiyaç ve beklentilerinin organizasyonlar tarafında iyi analiz edilmesini, ürünlerin kendi istedikleri şekilde üretilmesini ve hatta bireysel olarak kendilerine özel reklamların hazırlanmasını arzu etmektedirler (Çakır ve Eğinli, 2010:62).

Müşteri ilişkileri, bir organizasyonun müşteri ihtiyaçlarını anlamak yönünde ne ölçüde üzerinde durduğu ile tanımlanmıştır. Organizasyonlar, müşterilerinin gerçekten ihtiyaç duydukları bir ürün veya hizmeti sağladıklarını ve ürün veya hizmetlerinin mevcut ve ortaya çıkan müşteri ihtiyaçlarına karşı reaktif olup olmadığını görmek için, sürekli olarak kontrol etmeyi sağlarlar. Bu hedefleri gerçekleştirmek için organizasyonlar, müşterilerini davet etmek ve onlara üretim prosedürlerini göstermek, ürün veya hizmetleri hakkında geri bildirimde bulunmaya teşvik etmek ve yeni ürünleri hakkında bilgi vermek eğilimindedirler (Kim, 2010:50).

Müşteri ilişkileri müşteri tatmin unsurlarından birisidir, yani müşteri ilişkilerine önem verilmesi müşteri tatminini arttıracaktır. Müşteri ilişkileri ürünlerin satışından sonra da devam etmelidir. Satış sonrası hizmet birimleri kurularak müşterilerin tamir, onarım ve şikayet gibi istekleri de yerine getirilerek müşteri 
tatmini sağlanmış olacaktır (Küçük, 2012:314-315). Müşteri ilişkileri, müşterilerin ihtiyaç ve beklentilerinin belirlenmesinde de önemli rol oynamaktadır. Müşteri ihtiyaçlarının belirlenmesinde müşterilerle birebir görüşme, anket uygulama ve müşteri şikayetlerinin değerlendirilmesi etkili yöntemler arasında yer almaktadır (Efil, 2016:184).

Organizasyonda kurulacak olan bir Müşteri Ilişkileri Yönetimi (CRM) sistemi ile müşterilerin firma ile sürekli olarak ilişki halinde olması sağlanabilir ve bu şekilde müşterilerin arzu, talep ve şikâyetleri hakkında çalışanlar tarafından aranması da kolaylaştırılabilir. Bununla birlikte geçmişte yapılmış olan satışlar ve halen devam eden satışlar hakkında müşterilerin organizasyona geri bildirimde bulunmalarının yolu açılarak müşterilerle ilişkilerin canlı tutulması sağlanabilir ve bu şekilde onların firmaya bağılıkları arttırılabilir (Eren, 2016:154).

Deming, üretim hattının en önemli kısmının müşteri olduğunu belirtmiştir. Bu nedenle organizasyonlar müşterilerinin ihtiyaç ve beklentilerini iyi analiz ederek ürünlerini müşterilerinin isteklerine göre tasarlamalıdırlar. Memnun edilen müşteri organizasyona sadakat gösterecektir ancak bundan daha da önemlisi, memnun olmayan müşteri de organizasyona zarar verecektir. Çünkü yapılan araştırmalar göstermiştir ki memnun olan müşteriler organizasyon ve ürünle ilgili memnuniyetlerini üç kişiye anlatırken, memnun olmayan müşteriler on beş kişiye anlatmaktadır (Öztürk, 2013:31). Bu nedenle müşterilerle kurulacak olan iletişim TKY için önem arz etmektedir. Müşteri ilişkilerinde doğrudan pazarlama gibi yöntemler de kullanılabilir.

TKY, süreç odaklıdır. Müşteriler, iç müşteriler (yani organizasyon çalışanları) de dahil olmak üzere, organizasyon süreçlerinin bir parçasıdır. Bu müşteriler, gereksinimleri ve beklentileri ile birlikte tüm süreçlerde tanımlanmalıdır. Bir sonraki adım, bu gereksinimlerin ve beklentilerin nasıl yerine getirilebileceğinin planlanmasıdır. Deneyim ve sorunların tüm süreçlerde bilinmesi için müşterilerin geri bildirimlerde bulunması gerekir. Bu geribildirim hem ürünlerin hem de süreçlerin sürekli iyileştirilmesi için şarttır. Bunun etkili olabilmesinin en rasyonel yolu herkesin katılımı olarak görünmektedir (Dahlgaard vd., 2008:35).

Kalite yönetiminde hem intiyaçlarını tanımlamak hem de organizasyon için gerekli olan geribildirimi almak için, müşteriler ile çok yakın bağlantıları korumak önemlidir. Ürün tasarımında müşterilerinin ihtiyaçlarını analiz etmek için müşteri ile temasa geçilmek suretiyle tasarım sürecine aktif müşteri katılımı sağlamak ürün dizaynı sürecine katkı yapacaktır (Forza ve Filippini, 1998:3).

Organizasyonlar müşteri gereksinimlerini belirleyebilmek için mevcut ve potansiyel müşterileri ile tüm iletişim kanallarını kullanarak iletişim halinde olmalıdır. İşletmeler müşteri gereksinimlerini belirleyebilmek için aşağıda belirtiler uygulamaları yapabilirler (Halis, 2016:295):

- Müşterilere belirli aralıklarla ziyaretlerde bulunmak,

- Müşterilere ürünlerle ilgili anketler yapmak,

- Müşterilerle telefon görüşmeleri yaparak ürünlerle ilgili görüşlerini almak,

- Pazar analizleri yapmak,

- Müşteri şikayet ve memnuniyetlerinin değerlendirmesini yapmak,

- Odak gruplar ile uygulamalar yapmak.

\section{4. Çalışan iliş̧kileri}

Çalışan ilişkileri, çalışanların ne dereceye kadar kalite çabalarına ve kalite kararlarına katıldıkları, kalite sorumlulukları olduğu, üstün kalite performansının farkında oldukları, kalite konularını ele aldıkları ve kalite hakkındaki genel farkındalığı ne ölçüde geliştirdikleri ile tanımlanmıştır. Kalite yönetimi uygulamasının başarılı olması ancak, kalite sorumluluğu, bir organizasyon içindeki tüm çalışanlara ve bölümlere genişletilebilirse garanti edilebilir (Kim, 2010:46). 
Çalışanlara kalite kapsamında sadece en değerli varlıklarımız olduğunun vurgulanması yeterli olmayacaktır. Onlara aynı zamanda kalitenin yapıııları olduklarının da benimsetilmesi gerekmektedir. Çünkü kaliteyi insanlar yapmaktadır ve bir özdeyişte belirtildiği gibi 'bir organizasyon onu oluşturanlar kadar iyidir' Bu nedenle kalite yapıcıları olarak kalite uygulamalarına çalışanlar da dahil edilmelidir (Kanji ve Asher'den [1993] aktaran Dahlgaard vd., 2008:212)

Çalışan katılımı ancak endişelerin iş yerinden uzaklaştırılmasının ardından, yönetim, yetkilendirme ve uygun ortamı sağlandığında gerçekleşebilir. Kalite, organizasyon çapında bir süreç olduğundan, kalite sorunlarını araştırmada ve düzeltmede istisnasız olarak organizasyondaki herkesle diyalog halinde olunmalıdır (Kongpichayanond, 2013:28).

TKY'nin insanlara yönelik bir yaklaşımı vardır ve TKY organizasyona ilişkin davranışın birçok özelliğini bünyesinde bulundurur. Etkin TKY ortamları bir kurumun kalite hedeflerini gerçekleştirmesinde tüm çalışanların katıımını sağlar. Çalışanların tamamı kaliteden sorumlu tutulur ve çalışanlara bu sorumluluklarını yerine getirmeleri için araçlar ve eğitimler verilir. TKY, günlük organizasyon prosedürlerine en yakın olan çalışanların bu prosedürlerin kalitesini en iyi anlayabilecek ve iyileştirebilecek konumda olduğu varsayımına dayalıdır. TKY, yöneticiler ile çalışanlar arasında olumlu ilişkilerin kurulduğu ve insanların ellerinden geleni yapma konusunda motive oldukları bir ortam yaratmayı amaçlar (Karia ve Asaari, 2006:32).

\subsection{Kalite Performansı}

Kalite performansı finansal ve piyasa performansını geliştiren bir özelliğe sahiptir ve yazında bu etkiler ve performans geliştirme için neler yapılabileceğine ilişkin çeşitli açıklamalar bulunmaktadır. İlk olarak, bir organizasyon yüksek kalitede ürün ve hizmetler sunma konusunda bir üne kavuştuğunda, talebin esnekliği azalabilir ve bu da organizasyonun daha yüksek fiyat talep etmesini ve daha yüksek kazançlar elde etmesini sağlayabilir. İkincisi, atık azaltarak ve verimliliği artırarak ürün kalitesini artırmak karlılığı ve varlıkların getirisini artırabilir. Üçüncü olarak, yeniden işi azaltmak, daha az hurda getirmek ve üretkenliği artırmak suretiyle bir organizasyonun maliyetlerini düşürerek organizasyonun, kar marjını çekmeden ürün ve hizmetler için daha düşük fiyat teklif etmesini sağlayabilir. Dolayısıyla düşük fiyatlar pazar payını ve satışlarını artırabilir. Sonuç olarak kaliteyi artırmak daha fazla bağlılık, artan satış ve daha da rekabetçi bir konuma sahip olan daha memnun müşterilerin elde edilmesine olanak sağlayacaktır (Kaynak, 2003:418).

Hatalı üretilen ürün sayısındaki azalmalar, üretimdeki firelerin önlenmesi, ürünlerin sürekli iyileştirilmesi sonucu müşteri memnuniyetinin artırılması, üretilen ürün kalitesinin müşteri beklentileri doğrultusunda yükseltilmesi, zamanında ve hızlı teslimat, üretim maliyetlerinin düşürülmesi organizasyonların kalite performansını iyileştirecektir (Eren vd. 2005:205). Kalite performansının ölçümü için verimlilikteki artış, ürün teslim süresindeki azalış, hurda ve yeniden işleme maliyetlerindeki azalma, hatalı ürün sayısındaki azalma gibi göstergeler kullanılmaktadır.

\section{Değişkenler Arasındaki iliş̧kiler ve Araştırma Hipotezlerinin Kurulması}

Müşteri memnuniyetini artırmak üst yönetimin kararlılığıyla mümkündür. Üst yönetim, kalite amaçlarını ve planlarını müşteri memnuniyetine göre ana hatlarıyla belirler (Kim, 2010). Müşteri memnuniyetinin artırılması, üst yönetimin taahhüdü ile gerçekleştirilebilir. Üst düzey yönetici, müşteri memnuniyeti için kalite hedeflerini ana hatlarıyla belirlediğinde, çalışanlar bu hedefe katkıda bulunmak için kaynaklarını, tecrübelerini ve eylemlerini bu hedeflere yönelik önceliklendirirler (Kim vd., 2012:298). Kaynak ve Hartley (2008)" Yönetimin ziyaretler düzenleyerek, müşteri ihtiyaçları ve özellikleri hakkında ayrıntılı bilgi talep ederek ve ürün tasarımı ekibiyle birlikte müşterileri sürece dahil ederek ürün dizaynına müşteri katıımını teşvik edebilir" ifadesini kullanmaktadır (Ou vd.,2010:530).

Ahire ve Ravichandran (2001), ABD ve Kanada'da otomobil parçaları tedarikçileri endüstrisinde faaliyet gösteren 407 firma üzerinden yaptıkları bir çalışmada, firmaların, çalışanların ve tedarikçilerin gerçek TKY uygulaması öncesinde ve eş zamanlı olarak uygun teknik ve davranışsal hazırlıklarını sağlamaları gerektiğini tespit etmiş ve kurdukları yapısal eşitlik modelinin analizi sonucunda üst yönetimin liderliğinin 
müşteri odaklılığını, tedarikçi kalite yönetimini ve çalışan yönetimini pozitif yönde anlamlı olarak etkilediği; tedarikçi kalite yönetiminin ise öğrenmeyi pozitif yönde anlamlı olarak etkilediği bulgularına ulaşmışlardır.

Tari vd. (2007), İspanya'da 106 kalite sertifikasına sahip firma üzerinde yaptıkları araştırmada yapısal eşitlik modeli tekniği ile analiz yapmış ve analiz neticesinde liderliğin müşteri odaklılığını; öğrenmenin proses yönetimini ve sürekli iyileştirmeyi; müşteri odaklılığın ve tedarikçi yönetiminin proses yönetimini pozitif yönde anlamlı olarak etkilediği sonucuna ulaşmışlardır.

Bu bilgilerden hareketle aşağıdaki hipotez geliştirilmiştir.

H1: Kalite odaklı liderlik müşteri ilişkilerini pozitif yönde anlamlı olarak etkiler.

Yönetim liderliği, bir firmanın insan kaynaklarını harekete geçirme ve işletim süreçlerini geliştirme konusundaki çabalarını yoğunlaştırmaya yönelik bir değişikliğin başlatılmasının ardındaki ana itici güçtür. Bu değişikliği gerçekleştirerek, firmalar başarılı TZY uygulanma intimalini artırabilir. Yönetim liderliği, nitelikli tedarikçileri seçmek ve tedarikçilerden kaliteli malzeme temin edilmesini onaylamak için kritik önem taşır ve bu nedenle tedarikçi yönetimi performansı için kritik öneme sahiptir (Ou vd. 2010:529-530).

Yönetimin TKY çerçevesinde gerçekleştirdiği planlı ve programlı iletişim iş görenler arasındaki ilişkilerin gelişimine katkıda bulunur. TKY'nin başarısı organizasyondaki departmanlar arası koordinasyon, uyum ve dayanışmaya bağlıdır. Çünkü örgüt içerisindeki birimler başka birimlere ürün ve hizmet sunmaktadırlar. Eğer iletişim kopuk olursa zamanla müşterilerin değişen ihtiyaçlarına cevap veremeyecek hale gelinir. Birimler ürünlerle ilgili geri bildirimleri alamaz ve yaptıkları hizmetler hakkında değerlendirmede bulunamazlar (Halis, 2008:148-149).

Üst yönetim, kaliteye dayalı ilkeleri kullanarak çalışanları tasarım süreçlerine katılmaya, ekip çalışmalarını geliştirmeye ve üretkenliği artırmaya özendirebilir. ilgili tüm departmanların katılımını sağlayacak şekilde TKY'nde bir odak oluşturan ve departmanlar arası mevcut veya potansiyel çatışmaları çözümleyen üst yönetimdir (Kim, 2010:43).

H2: Kalite odaklı liderlik çalışan ilişkilerini pozitif yönde anlamlı olarak etkiler.

TKY'nin uygulanmasında yönetimin karmaşık bir liderlik rolü vardır. İyi eğitilmiş bir iş gücü olmadan bir kuruluşun operasyonlarını iyileştirmek mümkün değildir. Yeni ilkelerin ve araçların kullanımı konusunda çalışanları eğitmek için gereken kaynakları sağlayan ve çalışanın değişim sürecine dahil olmasını sağlayan çalışma ortamını oluşturan yönetimdir. Üst yönetim ise kalite ile ilgili eğitim için ihtiyaç duyulan kaynakları temin etmekten sorumludur. Katılımcı çalışanlar, kaliteyi iyileştirmeye yönelik belirgin bir stratejiyi iletmelidir. Bu fonksiyon kaliteye dayalı teşvik ve tazminat prosedürleri belirleyerek geliştirilebilir (Kaynak, 2003:414).

Eğitim kalite teknik ve araçları üzerine kurulmalıdır. Üst yönetim, bu yeni ilke ve araçların kullanımı konusunda çalışanlara eğitim verebilir. Kalite teknik ve araçlarının başarılı bir şekilde uygulanması için en önemli faktör üst yönetimin tam desteği ve taahhüdüdür. Yönetim, doğru zamanda, doğru kişilere, doğru eğitimi vermelidir (Tari vd., 2007:488).

Kaynak (2003), TKY'ni ve tam zamanında satınalmayı uygulayan ABD'de faaliyet gösteren 382 firmadan posta yoluyla anket göndererek elde ettiği verileri yapısal eşitlik modeli tekniği ile analiz ettikten sonra yönetimin liderliğinin çalışan ilişkileri, eğitim, tedarikçi kalite yönetimi ve ürün dizaynını pozitif yönde anlamlı olarak etkilediği ayrıca; çalışan ilişkilerinin kalite verisi ve raporlamayı; kalite verisi ve raporlamanın proses yönetimi, tedarikçi kalite yönetimi ve ürün dizaynını; tedarikçi kalite yönetimini firma envanter performansını ve proses yönetimini; ürün dizaynının proses yönetimi ve kalite performansını; proses yönetiminin kalite performansını; kalite performansının da finansal ve pazar performansını pozitif yönde anlamlı olarak etkilediği bulgusuna ulaşmıştır.

TKY'nin yönetim liderliği, süreç yönetimi, çalışan katılımı ve müşteri odaklılığı gibi boyutları, firmaların kalite performansını iyileştirmek için yaygın olarak kabul edilen faaliyetlerdir (Zehir vd., 2012:278). 
Naktiyok ve Küçük (2003), KOBi'ler üzerinde yaptıkları bir çalışmada liderliğin kalite performansını pozitif yönde anlamlı olarak etkilediğini tespit etmişlerdir. Çalışma sonuçlarına göre liderlik kalite performansını diğer TKY faktörlerinden daha yüksek oranda etkilemiştir.

H3: Kalite odaklı liderlik eğitimi pozitif yönde anlamlı olarak etkiler.

H4: Kalite odaklı liderlik kalite performansını pozitif yönde anlamlı olarak etkiler.

TKY üzerinde etkisi olan eğitim, çalışanların bilgi seviyesini ve organizasyon performansını artırmaktadır. Eş zamanlı olarak eğitim, diğer kuruluşlarla iletişim kurmak için de önemli bir faktördür. Ayrıca bu faktör müşteri memnuniyetini artırmada da temel teşkil eder. Eğitim, organizasyonda rekabet gücü, organizasyon performansında yükselme ve çalışanlar arasında işbirliği ve bunun gibi birçok avantajı gündeme getirmektedir. (Mojtahedzadeh, 2014:91).

Üretken olması gereken vasıflı çalışan sayısı çalışanların katılım düzeyi ile pozitif korelasyona sahiptir.

O halde eğitimlerdeki artışın çalışanın işine katılımında ve kalite ile ilgili meselelere yönelik farkındalıkta paralel bir artış sağlamasını beklemek makul görünmektedir (Kaynak, 2003:415).

Uygun eğitim, takım çalışmasının geliştirilmesi, hataların azaltılması ve iş doyumunun arttırıması için fırsatlar sunar. Özellikle, eğitim, çalışanların çalışma biçimiyle doğrudan ilgilidir. Çalışanlar, güçlü ekip çalışması oluşturmaları gerektiğinin farkında olduklarını kabul etmeleriyle birlikte bir organizasyon kalite yönetimini benimsediğinde çalışanlar yenilik çalışmalarında kaliteli teknikler ve kalite ilkelerini nasıl uygulayacaklarını öğrenmelidir (Kim vd., 2012:298).

Çalışan ilişkileri, çalışanların nitelikli çabalara katıldığı, kalite kararlarına katıldığı, kaliteyi sağlamak için sorumlulukları bulunduğunu, üstün kalite performansını tanımayı, kalite konularını ele almayı ve kaliteye ilişkin genel farkındalığını artırmayı ifade eder. Çalışanların kalite çalışmalarına katııımı, kalite verileri üretiminde, ürün tasarlamada ve kalite süreçlerini yönetmede kilit rol oynamaktadır. Kalite sorumluluğu, bir organizasyon içindeki tüm çalışanlara ve tüm departmanlara genişletilirse, TKYU'larının başarı sigortası olacaktır (Kim vd., 2012:298).

H5: Eğitim çalışan ilişkilerini pozitif yönde anlamlı olarak etkiler.

H6: Eğitim müşteri ilişkilerini pozitif yönde anlamlı olarak etkiler.

TKY felsefesi kapsamında kurulan etkin müşteri ilişkileri müşterilerden iyi bir geri bildirim alınması sonucu ürünlerin kalite performanslarına olumlu katkı sağlayacaktır. Kalite müşteriler için yapılmaktadır, dolayısıyla müşterilerle geliştirilen kalite odaklı ilişkiler organizasyonların kalite performansına olumlu katkı sağlayabilir. Aynı şekilde çalışan ilişkileri de organizasyon içi iletişim ve işbirliğini artırabileceğinden kaliteye odaklanmayı kolaylaştırabilecektir. Kalite odaklı çalışan ilişkileri de nihayetinde kalite performansını etkileyebilecektir.

H7: Müşteri ilişkileri kalite performansını pozitif yönde anlamlı olarak etkiler.

H8: Çalışan ilişkileri kalite performansını pozitif yönde anlamlı olarak etkiler.

\section{Yöntem}

Bu bölümde öncelikle araştırma modeline, araştırmanın ölçeklerine, ölçeklerin yapı geçerliği ve güvenilirliği testlerinden elde edilen sonuçlara ve araştırmanın demografik özelliklerine değinilmiştir. Ardından araştırma hipotezlerini test etmek amacıyla yapılan yapısal eşitlik modeli analizinin sonuçlarından bahsedilmiştir. 


\subsection{Araştırmanın Modeli}

Araştırmanın modeli Şekil 1'de verilmiştir.

Şekil 1. Araştırmanın Modeli

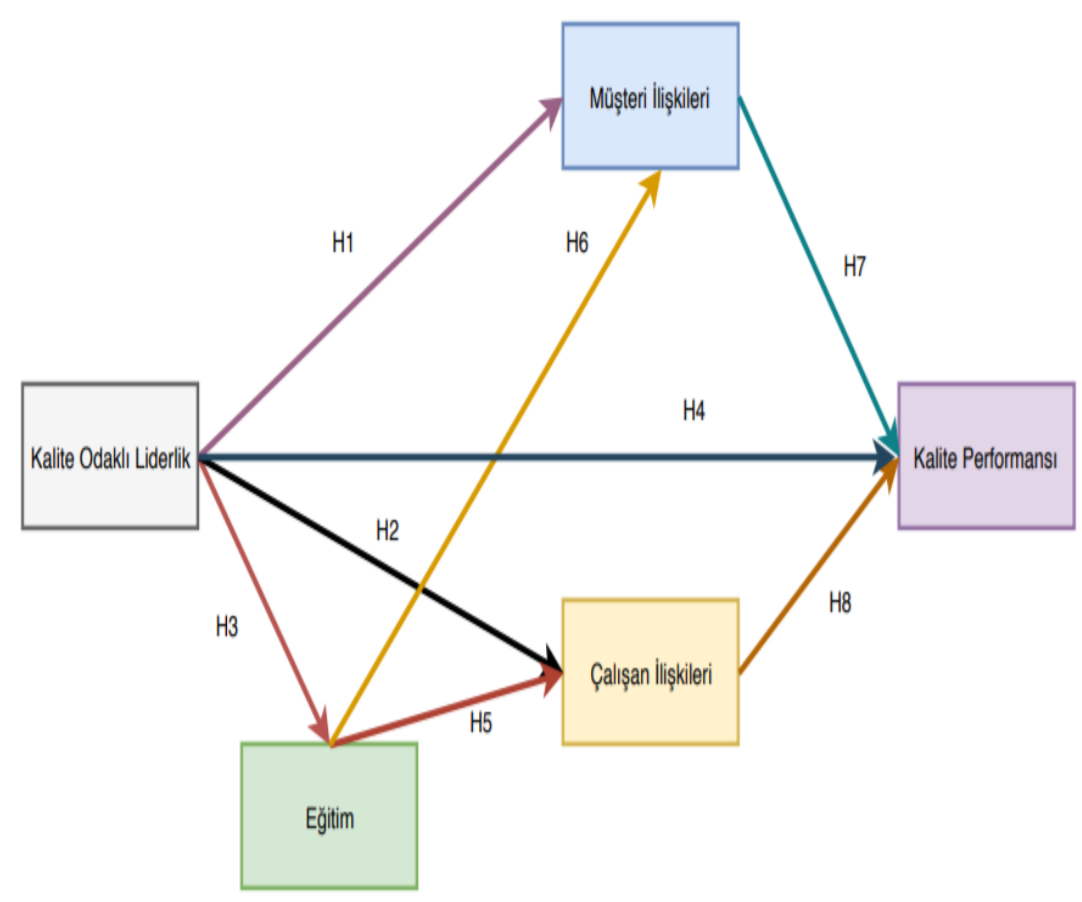

\subsection{Araştırmanın Örneklemi}

Araştırmanın örneklemini Gaziantep, Adıyaman ve Kahramanmaraş illerinde faaliyet göstermekte olan 170 imalat firması oluşturmaktadır. Araştırma yüz yüze görüşme yöntemi ve mail ortamında Mart 2017 - Haziran 2017 arasında toplanan anketlerden elde edilen veriler ile yapılmıştır. Toplamda 182 firmadan anket ile veri toplanmış fakat 12 anketin cevaplanmamış soru sayısının fazla olması nedeniyle analizler 170 firmadan toplanan anketler üzerinden yapılmıştır.

\subsection{Demografik Bulgular}

Araştırmaya katılan firmalar ve anketi cevaplandıran firma yetkililerinin bazı demografik özellikleri Tablo 1'de verilmiştir.

Tablo 1'de görüleceği üzere araştırmaya katılan firmaların 92'si Gaziantep, 47'si Kahramanmaraş ve $31^{\prime} i$ Şanlıurfa illerinde faaliyet göstermektedir. Firmaların 30'u gıda, 39'u tekstil, 21'i plastik/kimya, 19'u inşaat, 16'sı elektronik/bilgisayar sektörlerinde faaliyet göstermekte ve 6 firma ise diğer sektörlerde faaliyet göstermektedir. Çalışan sayısına göre araştırmaya katılan işletmeler büyük çoğunluğu küçük ve orta boy işletmedir. Araştırmaya katılan firmaların 54'ü (\%21,8'i) büyük işletmedir. Araştırmaya katılanların 43'ü firma sahibi/ortağı, 28'i genel müdür/yönetim kurulu başkanı, 99'u departman müdürüdür. Bu durum araştırmaya katılanların firmaları hakkında yeterli bilgiye sahip kişiler olduğunu ve verilerin doğru kişilerden elde edildiği göstermektedir. 
Tablo 1. Demografik Bulgular

\begin{tabular}{|c|c|c|c|}
\hline Faaliyet Ilii & Frekans & Yüzde & Kümülatif Yüzde \\
\hline Gaziantep & 92 & 54,1 & 54,1 \\
\hline Kahramanmaraş & 47 & 27,6 & 81,8 \\
\hline Şanlıurfa & 31 & 18,2 & 100 \\
\hline Toplam & 170 & 100 & \\
\hline Faaliyet Alanı & Frekans & Yüzde & Kümülatif Yüzde \\
\hline Gıda & 30 & 17,6 & 17,6 \\
\hline Tekstil & 39 & 22,9 & 40,6 \\
\hline Plastik/Kimya & 21 & 12,4 & 52,9 \\
\hline İnşaat & 19 & 11,2 & 87,1 \\
\hline Elektronik/Bilgisayar & 16 & 9,4 & 96,5 \\
\hline Diğer & 6 & 3,5 & 100 \\
\hline Toplam & 170 & 100.0 & \\
\hline Personel Sayısı & Frekans & Yüzde & Kümülatif Yüzde \\
\hline $0-50$ & 33 & 19,4 & 19,4 \\
\hline $51-150$ & 45 & 26,5 & 45,9 \\
\hline $151-250$ & 38 & 22,4 & 68,2 \\
\hline $251-350$ & 14 & 8,2 & 76,5 \\
\hline $351-450$ & 28 & 16,5 & 92,9 \\
\hline 451 ve üzeri & 12 & 7,1 & 100 \\
\hline Toplam & 170 & 100 & \\
\hline Firmadaki Pozisyonu & Frekans & Yüzde & Kümülatif Yüzde \\
\hline Firma sahibi/ ortağı & 43 & 25,3 & 25,3 \\
\hline Üretim Müdürü & 22 & 12,9 & 38,2 \\
\hline Pazarlama Müdürü & 33 & 19,4 & 57,6 \\
\hline Genel Müdür & 28 & 16,5 & 74,1 \\
\hline Kalite Müdürü & 26 & 15,3 & 89,4 \\
\hline Ar-Ge Müdürü & 18 & 10,6 & 100 \\
\hline Toplam & 170 & 100 & \\
\hline
\end{tabular}

\subsection{Araştırmanın Ölçekleri}

Liderlik, eğitim, çalışan ilişkileri ve müşteri ilişkileri ölçekleri Kim (2010), Saraph vd. (1989) ve Kaynak'ın (2003) çalışmalarından adapte etmiştir. Kalite performansı ölçeği ise Ingenbleek vd. (2013), Hwang vd. (2015), Kafetzopoulos vd. (2013), Kafetzopoulos vd. (2015), De Guimarães vd. (2016) ve Parvadavardini vd. (2016) çalışmalarından faydalanılarak hazırlanmıştır.

\section{5.Ölçeklerin Yapı Geçerliği ve Güvenilirliği}

Araştırma ölçeklerinin yapı geçerliği ve güvenilirliğini test etmek amacıyla keşfedici faktör analizi (KFA), doğrulayıcı faktör analizi (DFA) ve güvenilirlik analizleri yapılmıştır.

KFA sonucu elde edilen faktör yükleri Tablo 2'de verilmiştir. 
Tablo 2. Ölçekler Faktör Yükleri

\begin{tabular}{|c|c|}
\hline Maddeler & Faktör Yükü \\
\hline \multicolumn{2}{|l|}{ Liderlik } \\
\hline $\begin{array}{l}\text { L1: Üst düzey yöneticilerimiz ve departman yöneticileri kalite performansını } \\
\text { değerlendirir. }\end{array}$ & 890 \\
\hline L2: Departman sorumlularımız kalite iyileştirme sürecinde yer alır. & ,855 \\
\hline L3: Üst yönetimimizin kalite performansına yönelik hedefleri vardır. & ,800 \\
\hline $\begin{array}{l}\text { L4: Üst yönetimimiz kalite için kapsamlı bir amaç belirleme sürecini ortaya } \\
\text { koyar. }\end{array}$ & 840 \\
\hline L5: Kalite sorunları şirketin üst yönetim toplantılarında gözden geçirilir. & ,785 \\
\hline $\begin{array}{l}\text { L6: Üst yönetimimiz, kalitenin iyileştirmesini bir kar artırma yolu olarak } \\
\text { görmektedir. }\end{array}$ & ,681 \\
\hline Eğitim & Faktör Yükü \\
\hline $\begin{array}{l}\text { EG1: Firmamız çalışanlara özel çalışma becerileri eğitimi (teknik ve mesleki) } \\
\text { vermektedir. }\end{array}$ & 844 \\
\hline EG2: Firmamız çalışanlara kalite ile ilgili eğitim vermektedir. & ,901 \\
\hline EG3: Firmamız yöneticilere kalite ile ilgili eğitim vermektedir. & ,860 \\
\hline Müşteri iliş̧kileri & Faktör Yükü \\
\hline Mi1: Müşterilerimizle sık sık sıcak temas sağlarız. & ,724 \\
\hline Mi2: Çalışanlarımız müşterilerimizi yakından tanır. & ,755 \\
\hline $\begin{array}{l}\text { Mi3: Müşterilerimiz bize kalite ve teslimat performansı hakkında geri bildirim } \\
\text { yapar. }\end{array}$ & ,860 \\
\hline Mi4: Müşterilerimiz ofisimizi veya iş yerimizi ziyaret eder. & ,797 \\
\hline Çalışan İlişkileri & Faktör Yükü \\
\hline çi1: Firmamız çalışanlara kalite performansları hakkında geri bildirim yapar. & ,789 \\
\hline çi2: Kalite ile ilgili kararlarda her seviyeden çalışan yer alır. & ,805 \\
\hline $\begin{array}{l}\text { Çi3: Çalışanlar arasında kalite bilincini oluşturmak için sürekli bir faaliyet } \\
\text { içerisindeyiz. }\end{array}$ & 848 \\
\hline $\begin{array}{l}\text { Çi4: Çalışanlar üstün kalite performansı elde etmek için gerekenlerin } \\
\text { farkındadır. }\end{array}$ & ,816 \\
\hline Kalite Performansı & Faktör Yükü \\
\hline KP1: Firmamızın son üç yılına göre ürün kalitesi artmıştır. & ,697 \\
\hline KP2: ..........................verimlilik artmıştır & ,688 \\
\hline $\begin{array}{l}\text { KP3: .........................satışların \% si olarak hurda ve yeniden işleme maliyeti } \\
\text { azalmışır. }\end{array}$ & 737 \\
\hline KP4: ..........................satın alınan materyallerin teslim süreleri azalmıştır. & ,793 \\
\hline KP5: ..........................bitmiş ürünlerin müşterilere teslim süresi azalmıştır. & ,808 \\
\hline
\end{tabular}

KFA sonucu liderlik ölçeğinin faktör yükleri 0,681 ile 0,890 arasında elde edilmiştir. KMO testi neticesinde örneklem yeterlilik değerinin 0,874 olduğu ve örneklem büyüklüğünün faktör analizi için yeterli olduğu bulgusu elde edilmiştir. Ayrıca, Bartlett küresellik testinin anlamlı olması $[\chi 2(15)=565,794, \rho<0,01]$ maddeler arasındaki korelasyon ilişkilerinin faktör analizi için uygun olduğunu göstermektedir. Eğitim ölçeğinin faktör yükleri 0,844 ile 0,901 arasında elde edilmiştir. KMO testi neticesinde örneklem yeterlilik değerinin 0,707 olduğu ve örneklem büyüklüğünün faktör analizi için yeterli olduğu bulgusu elde edilmiştir. Ayrıca, Bartlett küresellik testinin anlamlı olması $[\chi 2(3)=204,262, \rho<0,01]$ maddeler arasındaki korelasyon ilişkilerinin faktör analizi için uygun olduğunu göstermektedir. Müşteri ilişkileri ölçeğinin faktör yükleri 0,724 ile 0,860 arasında elde edilmiştir. KMO testi neticesinde örneklem yeterlilik değerinin 0,756 olduğu ve örneklem büyüklüğünün faktör analizi için yeterli olduğu bulgusu elde edilmiştir. Ayrıca, Bartlett küresellik testinin anlamlı olması [x2 (6) $=201,459, \rho<0,01]$ maddeler arasındaki korelasyon ilişkilerinin faktör analizi için uygun olduğunu göstermektedir. Çalışan ilişkileri ölçeğinin faktör yükleri 0,789 ile 0,848 arasında elde edilmiştir. KMO testi neticesinde örneklem yeterlilik değerinin 0,769 olduğu ve örneklem büyüklüğünün faktör analizi için yeterli olduğu bulgusu elde edilmiştir. Ayrıca, Bartlett küresellik testinin anlamlı olması [X2 
(6) $=258,079, \rho<0,01]$ maddeler arasındaki korelasyon ilişkilerinin faktör analizi için uygun olduğunu göstermektedir. Kalite performansı ölçeğinin faktör yükleri 0,688 ile 0,808 arasında elde edilmiştir. KMO testi neticesinde örneklem yeterlilik değerinin 0,736 olduğu ve örneklem büyüklüğünün faktör analizi için yeterli olduğu bulgusu elde edilmiştir. Ayrıca, Bartlett küresellik testinin anlamlı olması $[\chi 2(10)=278,703, \rho<0, .01]$ maddeler arasındaki korelasyon ilişkilerinin faktör analizi için uygun olduğunu göstermektedir (Gürbüz ve Şahin, 2016:311; Dağlı, 2015:205; Kalaycı, 2014:322).

KFA sonrasında ölçeklere DFA yapılmıştır. DFA neticesinde elde edilen uyum iyiliği değerleri Tablo 3'de verilmiştir.

Tablo 3. DFA Uyum İyiliği Değerleri

\begin{tabular}{|l|c|c|c|c|c|c|c|}
\hline Değişken & $\mathbf{X}^{\mathbf{2}}$ & $\mathbf{d f}$ & $\mathbf{C M I N / d f}$ & GFI & CFI & TLI & RMSEA \\
\hline Liderlik & 12,806 & 7 & 1,829 & 0,975 & 0,99 & 0,978 & 0,07 \\
\hline Müşsteri Iliş̧kileri & 4,761 & 2 & 2,381 & 0,986 & 0,986 & 0,958 & 0,08 \\
\hline Çalışan Ilişkileri & 0,000 & 1 & 0,000 & 1,000 & 1,000 & 1,000 & 0,00 \\
\hline Kalite Performansı & 12,156 & 4 & 3,039 & 0,973 & 0,972 & 0,93 & 0,08 \\
\hline
\end{tabular}

DFA sonucu ölçeklerin kabul edilebilir uyum iyiliği değerlerini sağladıkları tespit edilmiştir (Meydan ve Şeşen, 2015:37; Gürbüz ve Şahin, 2016:337). Eğitim ölçeğinin 3 maddeden oluşması nedeniyle serbestlik derecesi sıfır olarak hesaplandığından uyum iyiliği değerleri raporlanmamıştır.

KFA ve DFA sonrası güvenilirlik analizi yapıımıştır. Güvenilirlik analizi sonucu elde edilen alfa katsayısı değerleri Tablo 4'de verilmiştir.

Tablo 4. Güvenilirlik Analizi

\begin{tabular}{|l|c|c|}
\hline Değişken & Cronbach Alpha Katsayısı & Madde Sayısı \\
\hline Liderlik &, 891 & 6 \\
\hline Eğitim &, 836 & 3 \\
\hline Müşteri Ilişkileri &, 786 & 4 \\
\hline Çalışan ilişkileri &, 829 & 4 \\
\hline Kalite Performansı &, 798 & 5 \\
\hline
\end{tabular}

Güvenilirlik analizi sonucu ölçeklerin güvenilirliklerinin iyi olduğu bulgusuna ulaşılmıştır (Kalaycı, 2014:405).

Korelasyon analizine ilişkin bulgular Tablo 5'de sunulmuştur.

Tablo 5. Korelasyon Analizi

\begin{tabular}{|l|c|c|c|c|c|c|c|}
\hline & Ort. & $\begin{array}{c}\text { Std. } \\
\text { Sapma }\end{array}$ & Liderlik & Eğitim & $\begin{array}{c}\text { Müşteri } \\
\text { ilişkileri }\end{array}$ & $\begin{array}{c}\text { Çalışan } \\
\text { ilişkileri }\end{array}$ & $\begin{array}{c}\text { Kalite } \\
\text { Performansı }\end{array}$ \\
\hline Liderlik & 4,19 & 0,61 & 1 & & & & \\
\hline Eğitim & 4,07 & 0,73 &, $609^{* *}$ & 1 & & & \\
\hline Müşteri ilişkileri & 4,11 & 0,69 &, $518^{* *}$ &, $434^{* *}$ & 1 & & \\
\hline Çalışan İlişkileri & 4,06 & 0,70 &, $561^{* *}$ &, $595^{* *}$ &, $589^{* *}$ & 1 & \\
\hline Kalite Performansı & 4,01 & 0,68 &, $564^{* *}$ &, $388^{* *}$ &, $452^{* *}$ &, $486^{* *}$ & 1 \\
\hline
\end{tabular}


Korelasyon analizi neticesinde eğitim ile liderlik arasında aynı yönde 0,01 anlamlılık düzeyinde orta, müşteri ilişkileri ile liderlik arasında 0,01 anlamlıık düzeyinde aynı yönde orta, müşteri ilişkileri ile eğitim arasında 0,01 anlamlıık düzeyinde aynı yönde düşük, çalışan ilişkileri ile liderlik, eğitim ve müşteri ilişkileri arasında 0,01 anlamlılık düzeyinde aynı yönde orta, kalite performansı ile liderlik arasında 0,01 anlamlıık düzeyinde aynı yönde orta ve kalite performansı ile eğitim, müşteri ilişkileri ve çalışan ilişkileri arasında aynı yönde 0,01 anlamlılık düzeyinde düşük bir ilişki olduğu bulgusu elde edilmiştir.

Ayrıca verilerin normal dağılıma sahip olup olmadığını test etmek amacıyla basıklık ve çarpıklık değerlerine bakılmıştır. Basıklık ve çarpıklık değerleri -2 ile +2 arasında tespit edildiğinden verilerin normal dağılıma sahip olduğu bulgusuna ulaşılmıştır.

\subsection{Araştırma Hipotezlerinin Test Edilmesi}

Araştırma hipotezlerini test etmek amacıyla yapısal eşitlik modeli kurulmuştur. Model Şekil 2'de, modelin uyum iyiliği değerleri Tablo 6'da ve regresyon ağırlığı değerleri ise Tablo 7'de sunulmuştur.

Şekil 2. Yapısal Eşitlik Modeli

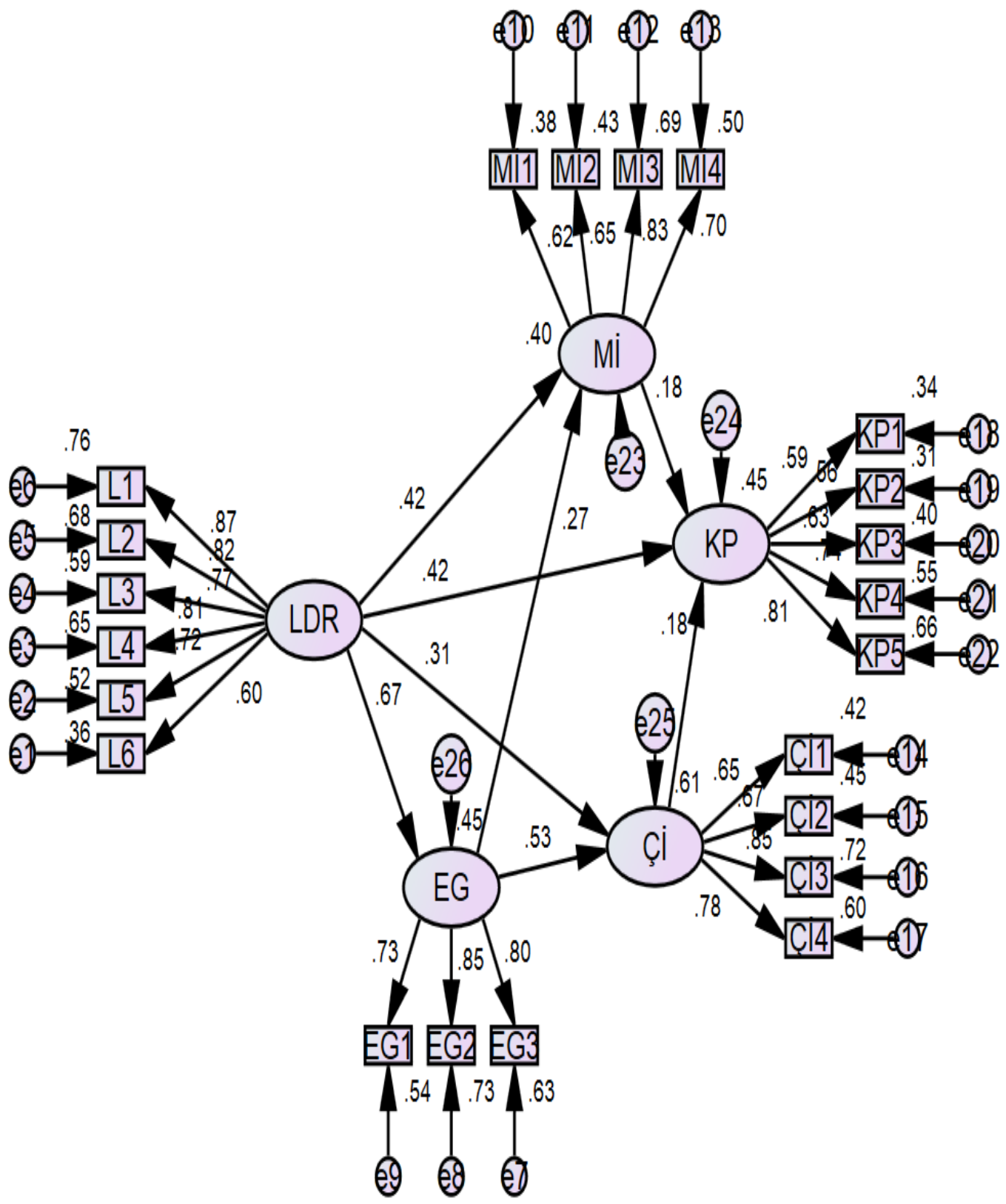


Kalite Odaklı Liderliğin Kalite Performansı Üzerindeki Etkisinin Yapısal Eşitlik Modeli İle Analizi

Tablo 6. Model Uyum İyiliği Değerleri

\begin{tabular}{|l|c|c|c|c|c|c|c|}
\hline & $\mathbf{X}^{2}$ & df & CMIN/df & CFI & GFI & TLI & RMSEA \\
\hline $\begin{array}{l}\text { Yapısal Eşitlik } \\
\text { Modeli }\end{array}$ & 347,987 & 196 & 1,775 & 0,923 & 0,854 & 0,909 & 0,068 \\
\hline
\end{tabular}

Yapısal eşitlik modelinin analizi sonucunda modelin kabul edilebilir uyum iyiliği değerlerini sağladığı tespit edilmiştir.

Tablo 7. Regresyon Ağırlığı Değerleri

\begin{tabular}{|l|l|l|r|r|r|r|}
\hline \multicolumn{3}{|c|}{ Test Edilen Yol } & Tahmin & Std. Hata & \multicolumn{1}{c|}{$\begin{array}{c}\text { Kritik } \\
\text { Oran }\end{array}$} & \multicolumn{1}{c|}{$p$} \\
\hline Eğitim & $<---$ & Liderlik & 0,673 & 0,138 & 6,369 & $* * *$ \\
\hline Müşteri Ilişkileri & $<---$ & Liderlik & 0,425 & 0,119 & 3,145 & 0,002 \\
\hline Çalışan İlişkileri & $<---$ & Liderlik & 0,312 & 0,114 & 2,873 & 0,004 \\
\hline Çalışan İlişkileri & $<---$ & Eğitim & 0,534 & 0,093 & 4,576 & $* * *$ \\
\hline Müşteri Iliş̧kileri & $<---$ & Eğitim & 0,267 & 0,082 & 2,203 & 0,028 \\
\hline Kalite Performansı & $<---$ & Liderlik & 0,415 & 0,11 & 3,135 & 0,002 \\
\hline Kalite Performansı & $<---$ & $\begin{array}{l}\text { Çalışan } \\
\text { ilişkileri }\end{array}$ & 0,175 & 0,096 & 1,452 & 0,146 \\
\hline Kalite Performansı & $<---$ & $\begin{array}{l}\text { Müşteri } \\
\text { ilişkileri }\end{array}$ & 0,179 & 0,108 & 1,571 & 0,116 \\
\hline
\end{tabular}

Yapısal eşitlik modelinin analizi sonucunda kalite odaklı liderliğin eğitimi, müşteri ilişkilerini, çalışan ilişkilerini ve kalite performansını pozitif yönde anlamlı olarak etkilediği, eğitimin de çalışan ilişkileri ve müşteri ilişkilerini pozitif yönde anlamlı olarak etkilediği bulgularına ulaşılamamıştır. Çalışan ilişkileri ve müşteri ilişkilerinin kalite performansı üzerindeki etkisi doğrulanamamıştır. Analiz sonucunda $H 1, H 2, H 3$, $\mathrm{H} 4, \mathrm{H} 5$ ve $\mathrm{H} 6$ hipotezleri doğrulanış $\mathrm{H} 7$ ve $\mathrm{H} 8$ hipotezleri ise doğrulanamamıştır.

\section{Sonuç}

Bu çalışmada kalite yönetiminin kritik başarı faktörlerinden olan yönetimin liderliğinin kalite performansı, eğitim, müşteri ve çalışan ilişkileri üzerindeki etkisi ile eğitimin müşteri ve çalışan ilişkileri üzerindeki etkisi araştırılmıştır. Ayrıca müşteri ve çalışan ilişkilerinin kalite performansı üzerindeki etkisi incelenmiştir. Bu amaçla Gaziantep, Kahramanmaraş ve Şanlıurfa illerinde faaliyet göstermekte olan 170 imalat firmasından anket ile veri elde edilmiştir. Elde edilen veriler ile öncelikle ölçeklerin yapı geçerliği ve güvenilirliği test edilmiştir. Ardından yapısal eşitlik modeli ile araştırma hipotezleri analiz edilmiştir. Yapılan analizler neticesinde kalite odaklı liderliğin eğitim, müşteri ilişkileri, çalışan ilişkileri ve kalite performansını pozitif yönde anlamlı olarak etkilediği bulgusuna ulaşımıştır. Ayrıca kalite odaklı eğitim faaliyetlerinin de müşteri ilişkileri ve çalışan ilişkilerini pozitif yönde anlamlı olarak etkilediği tespit edilmiştir. Bulunan sonuçların literatüre katkı sağlayacağı düşünülmektedir.

Lider yöneticiler istihdam etmek günümüz sanayi firmalarının en çok önem vermeleri gereken bir konudur. Liderler organizasyondaki en üst kademeden en alt kademeye kadar çalışanlarına kalite ile ilgili gerekli eğitimlerin verilmesi için en etkin rolü oynayan kişilerdir. Firmalar liderler istihdam ederlerse çalışanlarına kalite dahil bütün gerekli eğitimlerin verilmesi gerektiğine inanan ve organizasyonu bu doğrultuda harekete geçiren kişilerle çalışmış olurlar. Liderlik eğitimde olduğu gibi müşteri ilişkilerinin ve çalışan ilişkilerinin geliştirilmesinde de etkin rol oynamaktadır. Organizasyonda çalışanların müşteri odaklı 
bakış açısına sahip olmasını ve personel arasındaki etkin iletişim sağlanmasını teşvik edecek olan yine liderlerdir. Liderler eğer bu bilince sahip olurlarsa hem bu niteliklere sahip olanları istihdam edecek hem de gerek eğitimlerle gerekse kurum kültürünün belirlenmesi ile iş görenleri bu doğrultuda teşvik edecektir.

Eğitim, çalışan ilişkilerinin geliştirilmesinde etkin bir role sahiptir. Düzenli olarak yapılan eğitim toplantıları çalışanların fikir alışverişinde bulunması, farkı disiplinler arası sinerjinin kurulması üzerinde olumlu etki yapacaktır. Bu nedenle firmalar çalışanlarının gerek kalite konusunda gerekse ürün geliştirme, süreç yenileme, müşteri ilişkileri, inovasyon, pazarlama gibi konularda düzenli aralıklarla eğitim almalarını sağlamalıdır. Kalite alanında verilecek eğitimler kalite verilerinin elde edilmesi ve bu verilerin raporlanması için de destek olacak niteliktedir. Kalitenin felsefesi olan müşteri odaklılığın eğitimler sayesinde çalışanlara kazandırıması müşteri ilişkilerinin gelişmesine de önemli katkılar sağlayacaktır. Kalite anlayışı günümüzde kişiden kişiye farklılık göstermektedir. Bu nedenle potansiyel ve mevcut müşterilerin ürünler ile ilgili kalite algılarının öğrenilebilmesi için geliştirilen ilişkiler önemli rol oynamaktadır.

Bu çalışma imalat firmaları üzerinde yapılmıştır. Aynı çalışmanın hizmet sektöründe de yapılması literatüre önemli katkı sağlayacaktır. Çalışmada müşteri ve çalışan ilişkilerinin kalite performansı üzerindeki etkisi doğrulanamamıştır. Daha sonraki çalışmalarda müşteri ve çalışan ilişkilerinin kalite performansına olan etkisinde düzenleyici rolünün bulunup bulunmadığının araştırılması literatüre katkı sağlayacak bir çalışma olacaktır.

\section{Son Notlar}

* Bu çalışma Bülent Yıldız'ın hazırlamış olduğu "Toplam Kalite Yönetimi Uygulamalarının Inovasyon ve Firma Performansı Üzerindeki Etkisinde Çevresel Dinamizmin Düzenleyici Rolü" başıklı Doktora Tezi çalışmasından faydalanılarak hazırlanmıştır.

\section{Kaynaklar}

Ahire, S. L., \& Ravichandran, T. (2001). An innovation diffusion model of TQM implementation. IEEE Transactions on Engineering Management, 48(4), 445-464.

Antonaros, M. E. (2010). Gender differences in leadership style: A study of leader effectiveness in higher education. ERIC. Dissertation Abstracts International Section A: Humanities and Social Sciences, 71(5-A), 1550.

Bon, A. T., \& Mustafa, E. M. (2013). Impact of total quality management on innovation in service organizations: Literature review and new conceptual framework. Procedia Engineering, 53, 516-529.

Conti, T. (2012). Building total quality: A guide for management. Springer Science \& Business Media.

Çakır, S. Y., \& Eğinli, A. T. (2010). Memnun çalışanlar memnun müşteriler (1. Baskı). Ankara: Detay Yayıncılık.

Çetin, C. (2015). Toplam kalite yönetimi (5. Baskı). İstanbul: Beta Basım.

Dağlı, A. (2015). Örgütsel muhalefet ölçeğinin Türkçe’ye uyarlanması: Geçerlilik ve güvenirlik çalışması. Elektronik Sosyal Bilimler Dergisi, 14(53). 198-218.

Dahlgaard, J. J., Khanji, G. K., \& Kristensen, K. (2008). Fundamentals of total quality management. Routledge.

De Guimarães, J. C. F., Severo, E. A., Dorion, E. C. H., Coallier, F., \& Olea, P. M. (2016). The use of organisational resources for product innovation and organisational performance: A survey of the Brazilian furniture industry. International Journal of Production Economics, 180, 135-147.

Deming, W. E. (1986). Out of the crisis, Massachusetts Institute of Technology. Center for advanced engineering study, Cambridge, MA, 510.

Deming, W. E. (2000). The new economics: For industry, government, education. MIT press.

Efil, i. (2016). Toplam kalite yönetimi (8. Baskı). Bursa: Dora Basım-Yayın Dağııım.

Eren, E., Alpkan, L., \& Erol, Y. (2005). Temel fonksiyonel yeteneklerin firmaların yenilik ve finansal performansına etkileri. istanbul Ticaret Üniversitesi Sosyal Bilimler Dergisi, 4(7), 201-224.

Eren, E. (2016). Yönetim ve organizasyon çağdaş ve küresel yaklaşımlar (12. Baskı). İstanbul: Beta Basım. 
Ersoy, M. S., \& Ersoy, A. (2015). Kalite yönetimi, toplam kalite yönetimi ve kalite denetimi (2. Baskı). Ankara: İmaj Yayınevi.

Forza, C., \& Filippini, R. (1998). TQM impact on quality conformance and customer satisfaction: A causal model. International Journal of Production Economics, 55(1), 1-20.

Gürbüz, S., \& Şahin, F. (2016). Sosyal bilimlerde araştırma yöntemleri felsefe, yöntem, analiz (3. Baskı). Ankara: Seçkin Yayıncilık.

Halis, M. (2008). Toplam kalite yönetimi (2. Baskı). Adapazarı: Sakarya Yayıncılık.

Halis, M. (2016). Toplam kalite yönetimi, ISO 9000 kalite yönetim sistemleri (3. Baskı). Ankara: Seçkin Yayıncılık.

Hassan, M, Hassan, S., Shaukat, S., \& Nawaz, M. S. (2013). Relationship between TQM elements and organizational performance: An empirical study of manufacturing sector of Pakistan. Pakistan Journal of Commerce \& Social Sciences, 7(1), 01-18.

Hwang, D., Yang, M. G. M., \& Hong, P. (2015). Mediating effect of IT-enabled capabilities on competitive performance outcomes: An empirical investigation of ERP implementation. Journal of Engineering and Technology Management, 36, 1-23.

Ingenbleek, P., Frambach, R. T., \& Verhallen, T. M. (2013). Best practices for new product pricing: Impact on market performance and price level under different conditions. Journal of Product Innovation Management, 30(3), 560573.

Işığıçok, E. (2005). Toplam kalite yönetimi bakış açısıyla istatistiksel kalite kontrol (1. Baskı). Bursa: Ezgi Kitabevi.

Juran, J. M. (1989). Juran on leadership for quality: An executive handbook. Juran Institute, Inc. published by The Free Press, a division of MacMillan, Inc.

Kafetzopoulos, D., Gotzamani, K., \& Psomas, E. (2013). Quality systems and competitive performance of food companies. Benchmarking: An International Journal, 20(4), 463-483.

Kafetzopoulos, D., Gotzamani, K., \& Gkana, V. (2015). Relationship between quality management, innovation and competitiveness. Evidence from Greek companies. Journal of Manufacturing Technology Management, 26(8), 1177-1200.

Kalaycı, Ş. (2014). SPSS uygulamalı çok değişkenli istatistik teknikleri (6. Baskı). Ankara: Asil Yayın Dağıtım.

Kanji, G. K., \& Asher, M. (1993) Total quality management: A systematic approach. Oxford: Carfax Publishing Co.

Karia, N., \& Asaari, H. A. H. M. (2006). The effects of total quality management practices on employees' work-related attitudes. The TQM Magazine, 18(1), 30-43.

Kaynak, H. (2003). The relationship between total quality management practices and their effects on firm performance. Journal of Operations Management, 21(4), 405-435.

Kaynak, H., \& Hartley, J. L. (2008). A replication and extension of quality management into the supply chain. Journal of Operations Management, 26(4), 468-489.

Kıngır, S. (2013). Toplam kalite yönetimi (3. Baskı). Ankara: Nobel Akademik Yayıncılık.

Kim, D. Y. (2010). The impact of quality management practices on innovation (Unpublished PhD Thesis). Carleton University.

Kim, D.Y., Kumar, V., \& Kumar, U. (2012). Relationship between quality management practices and innovation. Journal of Operations Management, 30(4), 295-315.

Klefsjö, B., Bergquist, B., \& Garvare, R. (2007). TQM and business excellence, customers and stakeholders: do we agree on what we are talking about, and does it matter? Quality Management and Organizational Development. Lunds University, Campus Helsingborg.

Koçel, T. (2014). İşletme yöneticiliği (15. Baskı). İstanbul: Beta Basım.

Kongpichayanond, P. (2013). Penceived relationship among knowledge management, total quality management, and organization innovation performance: $A$ Thai study (Unpublished PhD Thesis). University of Minnesota.

Küçük, O. (2012). Toplam kalite yönetimi sınırsız iyileşme - EFQM mükemmellik modeli (3. bs.). Ankara: Seçkin Yayıncılık. Madu, C. N. (1998). Handbook of total quality management (1st ed.). USA: Springer Science Business Media B.V.

Meydan, C. H. \& Şeşen, H. (2015). Yapısal eşitlik modellemesi: AMOS uygulamaları (2. Baskı). Ankara: Detay Yayıncılık.

Mojtahedzadeh, R. (2014). The effect of quality culture and organisational performance in Iran car manufacturing companies (Unpublished PhD Thesis). Multimedia University Malaysia. 
Naktiyok A., \& Küçük O. (2003). Küçük ve orta büyüklükteki işletmelerde (KOBi) toplam kalite yönetimi (TKY) kritik faktörlerinin örgütsel performans üzerine etkileri. Erciyes Üniversitesi iktisadi ve Idari Bilimler Fakültesi Dergisi, 21, 43-65.

Ou, C. S., Liu, F. C., Hung, Y. C., \& Yen, D. C. (2010). A structural model of supply chain management on firm performance. International Journal of Operations \& Production Management, 30(5), 526-545.

Öztürk, A. (2013). Kalite yönetimi ve planlaması (1. Baskı). Bursa: Ekin Yayınevi.

Parvadavardini, S., Vivek, N., \& Devadasan, S. R. (2016). Impact of quality management practices on quality performance and financial performance: Evidence from Indian manufacturing companies. Total Quality Management \& Business Excellence, 27(5-6), 507-530.

Pekar, J. P. (1995). Total quality management: Quiding principles for application. American Society for Testing and Materials.

Reed, R., Lemak, D. J., \& Mero, N. P. (2000). Total quality management and sustainable competitive advantage. Journal of Quality Management, 5(1), 5-26.

Saraph, J. V., Benson, P. G., \& Schroeder, R. G. (1989). An instrument for measuring the critical factors of quality management. Decision Sciences, 20(4), 810-829.

Tari, J. J., Molina, J. F., \& Castejon, J. L. (2007). The relationship between quality management practices and their effects on quality outcomes. European Journal of Operational Research, 183(2), 483-501.

Thiagarajan, T., \& Zairi, M. (1997). A review of total quality management in practice: Understanding the fundamentals through examples of best practice applications-Part I. The TQM Magazine, 9(4), 270-286.

Wilkinson, A., Redman, T., Snape, E., \& Marchington, M. (1998). Managing with total quality management. Theory and practice. McMillan Business, Hong-Kong.

Zehir, C., Ertosun, Ö. G., Zehir, S., \& Müceldilli, B. (2012). Total quality management practices' effects on quality performance and innovative performance. Procedia - Social and Behavioral Sciences, 41(2012), 273-280. 
This Page Intentionally Left Blank 